\title{
Influence of sources of dietary vitamin $E$ on the maternal transfer of $\alpha$-tocopherol to fetal and neonatal guinea pigs as determined by a stable isotopic technique
}

\author{
N. Hidiroglou ${ }^{1}$, R. Madere ${ }^{1}$, L. R. McDowell ${ }^{2}$ and P. L. Toutain ${ }^{3}$ \\ ${ }^{1}$ Nutrition Research Division, Health Products and Food Branch, Health Canada, Banting Research Center (PL 2203C), \\ Tunneys Pasture, Ottawa, Ontario, Canada K1A-OL2 \\ ${ }^{2}$ University of Florida, Department of Animal Sciences, Gainesville, Florida, USA \\ ${ }^{3}$ UMR INRA-Ecole Nationale Veterinaire de Toulouse de Physiopathologie et Toxicologie Expérimentales, \\ Toulouse, F 31076, France
}

(Received 15 April 2002 - Revised 25 September 2002 - Accepted 11 October 2002)

\begin{abstract}
The accepted biological potencies of vitamin E (United States Phamacopeia, 1985) for $1 \mathrm{mg}$ allrac- $\alpha$-tocopheryl acetate (synthetic form) is $1.00 \mathrm{IU}$ and that of $1 \mathrm{mg}(R R R)$ - $\alpha$-tocopheryl acetate (natural form) is $1.36 \mathrm{IU}$. In the present study, a stable isotopic $\left({ }^{2} \mathrm{H}\right)$ technique was employed to evaluate the bioavailability of natural $v$. synthetic forms of vitamin $\mathrm{E}$ and to determine whether the potency of the forms is the stated relationship of 1.36:1.00 $(R R R)$ - $\alpha$-tocopheryl acetate:all-rac- $\alpha$-tocopheryl acetate. Sixty female in-bred guinea pigs received either 40 or $80 \mathrm{mg}$ vitamin $\mathrm{E} / \mathrm{kg}$ diet with equal levels of $(R R R)$ - $\alpha$-tocopheryl acetate and all-rac$\alpha$-tocopheryl acetate throughout gestation and lactation. At late-term pregnancy (day 50 or 60 ) and during early lactation, dams and their corresponding fetuses or neonates were killed and various tissues collected for subsequent $\alpha$-tocopherol analysis. Vitamin E analysis of fetal and neonatal tissues indicated a substantial transfer of ${ }^{2} \mathrm{H}$-labelled $\alpha$-tocopherol across the placenta and through the mammary gland. Total $\alpha$-tocopherol concentrations were significantly influenced by tissue type and dose level, but not by stage of gestation or lactation. The relative bioavailability $\left(\mathrm{d}_{3}: \mathrm{d}_{6}\right)$ across fetal and neonatal tissues was on average $1 \cdot 81: 1 \cdot 00$, with a range from 1.62:1.00 to 2.01:1.00. Maternal tissues had a mean ratio of 1.77:1.00. A higher relative bioavailability $(P \leq 0.05)$ was observed with natural compared with synthetic $\alpha$-tocopherol as shown by a higher $\mathrm{d}_{3}: \mathrm{d}_{6}$ ratio in all tissues examined. Vitamin $\mathrm{E}$ was highest in colostrum on day 2 then declined through to day 5. Results from this present experiment further question the accepted biological potencies of natural:synthetic $\alpha$-tocopheryl acetate of 1·36:1.00.
\end{abstract}

Vitamin E sources: Bioavailability: Stable isotopes: Guinea pig

In Canada and the USA, $5 \%$ of newborn infants are classified as low-birth-weight infants, while in many developing countries the value is $>20 \%$ (Health Canada, 1995). Verylow-birth-weight, low-birth-weight and premature infants are frequently vitamin $\mathrm{E}$ deficient, with an increased susceptibility to $\mathrm{O}_{2}$ toxicity (Mino \& Nishino, 1973; Kelly, 1993). Low blood vitamin $\mathrm{E}$ in preterm infants is associated with low tissue vitamin E levels (Kelly et al. 1990). The premature infant is susceptible to certain major clinical problems, including chronic lung disease, intra-ventricular haemorrhage and retinopathy of prematurity, which have been attributed at least in part to low vitamin E levels
(Kelly, 1993). These disorders have been associated with vitamin $\mathrm{E}$ deficiency, with a major function of the vitamin being a chain-breaking lipid-soluble antioxidant, protecting membrane polyunsaturated fatty acids from free radical oxidative damage (Kelly et al. 1990).

As a therapeutic agent, vitamin E may have a beneficial role in newborn infants, particularly preterm infants (including low- and very-low-birth-weight infants), for ameliorating conditions associated with oxidant stress, including bronchopulmonary dysplasia (Ehrenkranz et al. 1978, 1979), retrolental fibroplasia (Johnson et al. 1995) and intra-ventricular haemorrhage (Chiswick et al. 1982; 
Speer et al. 1984). However, the potential benefits of vitamin $\mathrm{E}$ supplementation in the prevention or reduced severity of the abnormalities mentioned earlier is still uncertain and much debated.

There has been little research into the efficacy of supplemental vitamin $\mathrm{E}$ to women at risk of delivering lowbirth-weight or premature infants, despite evidence of a potential therapeutic role of the vitamin. For most small animals used as laboratory models, the pharmacokinetics or deposition of vitamin E during fetal development and mammary transfer have largely been unstudied. In addition, very little information is available on the bioavailability of the two principle commercial sources of $\alpha$-tocopherol, those being $(R R R)$ - $\alpha$-tocopheryl acetate (natural, single stereoisomeric form, $\mathrm{d}_{3}$ ) and all-rac- $\alpha$-tocopheryl acetate (synthetic form, approximately equimolar mixture of eight stereoisomers, $\mathrm{d}_{6}$ ) upon maternal-fetal-neonatal tissue $\alpha$-tocopherol levels following administration to pregnant and lactating animals.

The US National Formulary provides vitamin E potencies as follows: $1 \mathrm{mg}$ of all-rac- $\alpha$-tocopheryl acetate $=1.0 \mathrm{IU}$ and $1 \mathrm{mg}$ of $R R R$ - $\alpha$-tocopheryl acetate $=1 \cdot 36 \mathrm{IU}$ (United States Phamacopeia, 1985). These relationships comparing natural with synthetic $\alpha$-tocopherol from both animal and human studies have been challenged. Natural $\alpha$-tocopherol has been shown to have significantly higher relative bioavailability than synthetic vitamin E (Hidiroglou et al. 1992; Burton \& Ingold, 1993; Mahan et al. 2000; Hidiroglou et al. 2001).

In the present experiment, a stable isotopic technique was employed to evaluate the relative bioavailability of natural $v$. synthetic forms of the vitamin. The objective was to determine the extent of transfer of various forms of vitamin $E$ including two dose levels $\left(d_{3}\right.$ and $\left.d_{6}\right)$ from pregnant guinea pigs to the fetuses and to neonatal pups as well as to measure the relative bioavailability of the two principle commercial sources of vitamin E.

\section{Materials and methods}

\section{Animals and diets}

In-bred Hartley-strain guinea pigs (sixty females and fifteen males) weighing approximately $200 \mathrm{~g}$ were obtained from Elm Hill Breeding Labs, Chelmsford, MA, USA. Animals were housed individually in plastic cages with bedding material in a room with controlled temperature $\left(23 \pm 2^{\circ} \mathrm{C}\right)$, relative humidity $(55 \pm 2 \%)$ and light (lights on 06.00 to 18.00 hours). The experimental and animal handling procedures were approved by the Animal Care Committee of Health Canada and were performed in accordance with the guidelines of the Canadian Council of Animal Care (1993) as specified in the Guide to the Care and Use of Experimental Animals. Animals were fed a Reid-Briggs diet (Dyets Inc., Bethelehem, PA, USA) ad libitum (Table 1) until reaching sexual maturity. At approximately $450 \mathrm{~g}$ body weight, the animals were group-housed to have three females and one male. Timed pregnancies were achieved by monitoring daily for the presence of sperm, determined by vaginal smears. At day 1 of assumed pregnancy, guinea pigs were then switched
Table 1. Modified Reid-Briggs guinea pig diet composition ( $\mathrm{g} / \mathrm{kg}$ diet)

\begin{tabular}{lr}
\hline Ingredient & \multicolumn{1}{c}{$\mathrm{g} / \mathrm{kg}$} \\
\hline Casein (vitamin-free) & $300 \cdot 00$ \\
Maize starch & 200.00 \\
Sucrose & 97.88 \\
Dextrose & 71.00 \\
Cellulose & 150.00 \\
Tocopherol-stripped maize oil $†$ & 73.00 \\
Salt mix $§$ & 90.00 \\
Vitamin mix |ף & 10.00 \\
Choline chloride & 4.00 \\
Ascorbic acid & 4.00 \\
\end{tabular}

${ }^{*}$ Reid \& Briggs.

† Stabilized with tert-butylhydroxyquinone $(0.20 \mathrm{~g} / \mathrm{kg})$.

$\ddagger$ No. 200151; Dyets Inc, Bethlehem, PA, USA.

$\S \mathrm{D}-\alpha$-Tocopheryl acetate provided at $40 \mathrm{mg} / \mathrm{kg}$ diet (non- ${ }^{2} \mathrm{H}$-labelled vitamin E). This level of vitamin $\mathrm{E}$ was given during non-pregnant phase.

|l No. 300151; Dyets Inc, Bethlehem, PA, USA.

I At day 1 of assumed pregnancy, females were switched from non- ${ }^{2} \mathrm{H}$-labelled vitamin $\mathrm{E}$ ( $40 \mathrm{mg} / \mathrm{kg}$ diet) to ${ }^{2} \mathrm{H}$-labelled vitamin $\mathrm{E}$ at two dose levels: (1) $20 \mathrm{mg}(R R R)$ - $\alpha$-tocopheryl acetate $\left(\mathrm{d}_{3}\right)+20 \mathrm{mg}$ all-rac $\alpha$-tocopheryl acetate $/ \mathrm{kg}$ $\left(\mathrm{d}_{6}\right) ; \quad(2) \quad 40 \mathrm{mg} \quad(R R R)$ - $\alpha$-tocopheryl acetate $\left(d_{3}\right)+40 \mathrm{mg}$ all-rac $\alpha$-tocopheryl acetate $\left(\mathrm{d}_{6}\right) / \mathrm{kg}$.

to the identical Reid-Briggs diet as used during the nonpregnant phase, except that the non- ${ }^{2} \mathrm{H}$-labelled vitamin E (at a level of $40 \mathrm{mg} / \mathrm{kg}, \mathrm{d}_{0}$ ) was replaced with equimolar mixtures of ${ }^{2} \mathrm{H}$-labelled-vitamin E $\left(20 \mathrm{mg} / \mathrm{kg}\left(\mathrm{d}_{3}\right)+20 \mathrm{mg} /\right.$ $\mathrm{kg}\left(\mathrm{d}_{6}\right)$ or $40 \mathrm{mg} / \mathrm{kg}\left(\mathrm{d}_{3}\right)+40 \mathrm{mg} / \mathrm{kg}\left(\mathrm{d}_{6}\right)$ as the sole dietary sources of vitamin E) throughout the entire gestation and lactation periods until the scheduled time of killing. The sixty pregnancy-timed guinea pigs were randomly assigned to ${ }^{2} \mathrm{H}$-labelled dietary vitamin $\mathrm{E}$ level as well as killing dates that included two late-term gestation periods (days 50 and 60) and four postpartum lactation periods (days 1, 2, 4 and 5). There were five dams for each of the six time-periods. At the scheduled date, blood was collected from the abdominal aorta while under halothane anaesthesia $\left(2 \%\right.$ in $\left.\mathrm{O}_{2}\right)$ in pregnant and lactating dams as well as their corresponding fetuses or pups, as were various tissues. Tissues (ovaries, spleen, leg muscle, lung, liver, kidney, heart, brain and adrenal gland) were immediately weighed and promptly stored at $-75^{\circ} \mathrm{C}$. Blood samples (in heparinised tubes) were centrifuged at $1500 \mathrm{~g}$ for $15 \mathrm{~min}$ at $4^{\circ} \mathrm{C}$ immediately after sampling to obtain plasma and quickly stored at $-75^{\circ} \mathrm{C}$ until analysed for $\alpha$-tocopherol $\left({ }^{2} \mathrm{H}\right.$-labelled and non- ${ }^{2} \mathrm{H}$-labelled). In addition, milk samples were collected solely at the time of scheduled killing: does were separated from their offspring at the time of morning killing for a period up to $2 \mathrm{~h}$ to facilitate let-down response and milk collection. Milk samples from lactating animals (approximately $5 \mathrm{ml}$ ) were obtained by hand milking, collected into screw-capped glass vials and stored at $-75^{\circ} \mathrm{C}$ for subsequent $\alpha$-tocopherol determinations. Placentas were also collected at days 50 and 60 of gestation and promptly stored at $-75^{\circ} \mathrm{C}$ until analysed for $\alpha$-tocopherol $\left({ }^{2} \mathrm{H}\right.$-labelled and non- ${ }^{2} \mathrm{H}$-labelled). 


\section{Analytical measurements}

Vitamin E was extracted from plasma and milk by the ethanol-heptane method and from tissues by the SDS method (Burton et al. 1985; Ingold et al. 1987). An internal standard $\mathrm{d}_{9}-\alpha-\mathrm{T}-\mathrm{OH}$ was added $(25 \mu \mathrm{l}, 6 \mathrm{nmol})$ immediately prior to extraction of each sample. The heptane lipid extract was passed through an analytical HPLC silica gel normal phase column $(250 \times 4 \mathrm{~mm}$ Lichrosorb Si 60 (5 um particle size); Supelco, Bellefonte, PA, USA) and the eluant was monitored at $290 \mathrm{~nm}$ excitation and $330 \mathrm{~nm}$ emission for the $\alpha$-tocopherols, which were subsequently collected automatically by using a Foxy Fraction Collector (Lincoln, NE, USA). The recovered $\alpha$-tocopherol was derivatised to trimethylsilyl ether derivatives after removal of the HPLC eluent by evaporation under a stream of $\mathrm{N}_{2}$ (Ingold et al. 1987). Pyridine $(100 \mu \mathrm{l})$ and $N, O$-bis-(trimethylsilyl) trifluroacetamide with trimethylchlorosilane $(50 \mu \mathrm{l}, 10 \mathrm{ml} / \mathrm{l}$; Pierce, Rockford, IL, USA) was added to the purified extracts of vitamin $\mathrm{E}$ and heated at $70^{\circ} \mathrm{C}$ for $15 \mathrm{~min}$. The $\alpha$-tocopherol trimethylsilyl ethers were injected $(1 \mu \mathrm{l})$ into a $12 \mathrm{~m} \times 0.2 \mathrm{~mm}$ internal diameter ULTRA-1 (OV 101 methyl silicone) capillary column in a Hewlett-Packard benchtop model 5995 GC-MS (Hewlett-Packard, Toronto, Ontario, Canada), operating in the single-ion monitoring mode (Ingold et al. 1987). The $502\left(\mathrm{~d}_{0}\right), 505\left(\mathrm{~d}_{3}\right), 508$ $\left(\mathrm{d}_{6}\right)$ and $511\left(\mathrm{~d}_{9}\right)$ parent trimethylsilylether molecular ions $(\mathrm{m} / \mathrm{z})$ were monitored continuously and their corresponding peak areas integrated to give the relative abundance of each tocopherol. GC-MS was also used to confer dietary ${ }^{2} \mathrm{H}$-labelled $\alpha$-tocopherol concentrations as well as the molar ratios from the mixture of ${ }^{2} \mathrm{H}$-labelled tocopherols. GC-MS was used to determine the percentage purity in labelling with ${ }^{2} \mathrm{H}$ within the chroman ring structure of $\alpha$-tocopherol. ${ }^{2} \mathrm{H}$-labelled tocopherol compounds $\left(\mathrm{d}_{3}\right.$ and $\mathrm{d}_{6}$ ) were synthesised and supplied by Eastman Chemical Company (Kingsport, TN, USA).

\section{Statistical analysis}

The statistical analysis was carried out using SYSTAT (version 8.0; SPSS Inc., Chicago, IL, USA). All results are reported as mean values and standard deviations. The dam concentrations were analysed using the following general linear model (GLM1):

$$
\begin{aligned}
\mathrm{Y}_{\mathrm{ijkl}}= & \text { constant }+ \text { dose }_{\mathrm{i}}+\text { status }_{\mathrm{j}}+(\text { dose } \times \text { status })_{\mathrm{ij}} \\
& + \text { tissue }_{\mathrm{k}}+\left(\text { dose } \times \text { tissue }_{\mathrm{ik}}+(\text { tissue } \times \text { status })_{\mathrm{kj}}\right. \\
& +(\text { tissue } \times \text { dose } \times \text { status })_{\mathrm{kij}}+\text { dam }_{\mathrm{l}}(\text { dose } \times \text { status })_{\mathrm{ij}} \\
& +\varepsilon_{\mathrm{ijkl}}
\end{aligned}
$$

where: $Y_{i j k l}$ is the dependent variable for dose $_{i}$, status ${ }_{j}$, tissue $_{\mathrm{k}}$ and dam ; dose $_{\mathrm{i}}$ is the fixed effect of dose $\mathrm{e}_{\mathrm{i}}(\mathrm{i}=1$ or $2(40$ or $80 \mathrm{mg} / \mathrm{kg}))$; status $_{j}$ is the fixed effect of status $(\mathrm{j}=1$ to 6 (pregnancy (days 50 and 60 ) and postpartum (days 1, 2, 4 and 5)) or $\mathrm{j}=1$ to 2 (prepartum $v$. postpartum)); tissue $_{k}$ is the fixed tissue effect of tissue ( $k=1$ to 10), i.e. adrenal gland, brain, heart, kidney, liver, lung, leg muscle, ovary, spleen and plasma; (dose $\times$ status) $)_{\mathrm{ij}}$ is an interaction term between dose $e_{i}$ and status ${ }_{j}$; $\left(\right.$ dose $\times$ tissue $_{\text {ik }}$ is an interaction term between dose $_{i}$ and tissue $e_{k}$; (tissue $\times$ status $)_{\mathrm{kj}}$ is an interaction term between tissue $_{\mathrm{k}}$ and status $\mathrm{j}_{\mathrm{j}}$; (tissue $\times$ dose $\times$ status $)_{\text {kij }}$ is an interaction term between tissue ${ }_{k}$, dose $_{\mathrm{i}}$ and status $\mathrm{j}_{\mathrm{j}}$; dam $_{1}$ (dose $\times$ status $_{\mathrm{ij}}$ is the random effect of dam $_{1}$ nested in (dose $\times$ status) $)_{\mathrm{ij}} ; \varepsilon_{\mathrm{ijkl}}$ is the random residual error.

Two different error terms were used in this model: the term dam (dose $\times$ status) was used to test the dose, status and (dose $\times$ status) effect (i.e. effect in the mainplot). The residual error term $\left(\varepsilon_{\mathrm{ijkl}}\right)$ was used to test all other effects, i.e. tissue, (tissue $\times$ dose), (tissue $\times$ status), (dose $\times$ tissue $\times$ status), i.e. the effect in the subplot. The first step consisted of examination of the significance of the interacting terms. When the interacting terms were significant, the data were analysed with appropriate GLM submodels.

Analysis of the results from fetuses and pups was carried out in two steps. GLM1 was used in the first step, but the residual (i.e. $\varepsilon_{\mathrm{ijkl}}$ ) included three sources of variations: $(\text { dam } \times \text { tissue })_{\mathrm{kl}}$; fetus $\left(\mathrm{dam}_{1}\right)$, i.e. random effects of fetus nested in dam $_{1}$; within fetus, i.e. residual. Thus, a second GLM (GLM2) of the following form was used:

$$
\begin{aligned}
\mathrm{y}_{\mathrm{mkl}}= & \mu+\text { tissue }_{\mathrm{k}}+\text { dam }_{1}+\left(\text { dam } \times \text { tissue }_{\mathrm{kl}}\right. \\
& + \text { fetus }_{\mathrm{m}}(\text { dam })_{1}+\varepsilon_{\mathrm{klm}} .
\end{aligned}
$$

These two GLM models were used to perform the following tests: (1) dam (dose $\times$ status) of GLM1 were used as mean square factors to test dose, status and (dose $X$ status), i.e. effect in main plot; (2) the residual of GLM2, i.e. $\varepsilon_{\mathrm{klm}}$, was used to test tissues factors of GLM2 and all interactions involving tissues in GLM1 (dam $\times$ tissue), (dose $\times$ tissue), (tissue $\times$ status), (tissue $\times$ dose $\times$ status), i.e. the effect in the subplot. Only those dams with at least two fetuses were considered in these two-step analyses. As in the dam analyses, different submodels were built whenever the interactions were significant.

\section{Results}

\section{Maternal tissue response}

Tissue vitamin E concentrations. Tissue and plasma concentrations in guinea pig dams according to dose level (either 40 or $80 \mathrm{mg} / \mathrm{kg}$ vitamin $\mathrm{E}$ ) and physiological status (pre- $v$. postpartum) are presented in Table 2. Total $\alpha$-tocopherol concentrations were significantly $(P<0 \cdot 001)$ influenced by the type of tissue and dose level (40 $v$. $80 \mathrm{mg} / \mathrm{kg}$ ) of vitamin $\mathrm{E}$, while the stage of gestation or lactation phase had no significant impact $(P>0.05)$.

As the status factor (overall pre-and postpartum) showed a significant interaction with the dose $(P<0.001)$ and with the tissue $(P=0.063)$, the status effect was investigated using submodels.

For tissue and the two dose levels (40 and $80 \mathrm{mg} / \mathrm{kg}$ ), a multiple comparison using Bonferroni's test showed no significant differences between tissues, except for the ovary and adrenal gland, which had significantly higher concentrations $(P<0.001)$ than the other tissues. The overall plasma:tissues values (for all status and doses) were: leg muscle $2 \cdot 3$, kidney $2 \cdot 8$, brain $3 \cdot 5$, heart $4 \cdot 3$, liver $5 \cdot 8$, spleen $6 \cdot 4$, lung $7 \cdot 1$, ovary $28 \cdot 3$, adrenal gland $97 \cdot 3$, indicating that all tissues were able to accumulate vitamin $\mathrm{E}$. 
Table 2. Total vitamin E concentrations in tissues of female guinea pigs pre- and postpartum ${ }^{*}$ (Mean values and standard deviations)

\begin{tabular}{|c|c|c|c|c|c|c|}
\hline \multirow[b]{2}{*}{ Tissue } & \multirow[b]{2}{*}{ Dose } & \multicolumn{2}{|c|}{ Prepartum } & \multicolumn{2}{|c|}{ Postpartum } & \multirow{2}{*}{$\begin{array}{l}\text { Significance of effect } \\
\text { pre- } v \text {. postpartum: } P \neq\end{array}$} \\
\hline & & Mean & SD & Mean & SD & \\
\hline \multirow[t]{2}{*}{ Adrenal gland $(\mathrm{nmol} / \mathrm{g})$} & 40 & 950 & 271 & 1055 & 317 & NS \\
\hline & 80 & 1625 & 441 & 1709 & 600 & NS \\
\hline \multirow{2}{*}{ Brain $(\mathrm{nmol} / \mathrm{g})$} & 40 & 40 & 4 & 47 & 12 & 0.063 \\
\hline & 80 & 40 & 8.6 & 57 & 11 & $<0.001$ \\
\hline \multirow{2}{*}{ Heart $(\mathrm{nmol} / \mathrm{g})$} & 40 & 50 & 10 & 47 & 9 & NS \\
\hline & 80 & 62 & 18 & 74 & 22 & NS \\
\hline \multirow[t]{2}{*}{ Kidney $(\mathrm{nmol} / \mathrm{g})$} & 40 & 28 & 7 & 34 & 8 & 0.069 \\
\hline & 80 & 40 & 9 & 49 & 15 & 0.078 \\
\hline \multirow{2}{*}{ Liver (nmol/g) } & 40 & 55 & 21 & 69 & 17 & 0.054 \\
\hline & 80 & 88 & 35 & 100 & 32 & NS \\
\hline \multirow{2}{*}{ Lung (nmol/g) } & 40 & 76 & 14 & 84 & 19 & NS \\
\hline & 80 & 110 & 41 & 116 & 32 & NS \\
\hline \multirow{2}{*}{ Leg muscle $(\mathrm{nmol} / \mathrm{g})$} & 40 & 23 & 4 & 26 & 7 & NS \\
\hline & 80 & 34 & 13 & 42 & 12 & NS \\
\hline \multirow[t]{2}{*}{ Ovary $(\mathrm{nmol} / \mathrm{g})$} & 40 & 331 & 59 & 300 & 91 & NS \\
\hline & 80 & 454 & 235 & 480 & 196 & NS \\
\hline \multirow{2}{*}{ Spleen $(\mathrm{nmol} / \mathrm{g})$} & 40 & 50 & 14 & 82 & 24 & $<0.001$ \\
\hline & 80 & 91 & 22 & 115 & 30 & $<0.05$ \\
\hline \multirow{2}{*}{ Plasma (nmol/ml) } & 40 & $5 \cdot 1$ & 1.7 & $13 \cdot 8$ & 5.8 & $<0.001$ \\
\hline & 80 & $7 \cdot 7$ & $2 \cdot 2$ & 21.5 & 8.6 & $<0.001$ \\
\hline
\end{tabular}

${ }^{*}$ Dams were supplemented daily from day 1 of pregnancy until killing with an equimolar mixture of ${ }^{2} \mathrm{H}$-labelled vitamin $\mathrm{E}$ at $40 \mathrm{mg} / \mathrm{kg}$ (i.e. $20 \mathrm{mg}(R R R)-\alpha$-tocopheryl acetate $\left(\mathrm{d}_{3}\right)$ and $20 \mathrm{mg}$ all-rac- $\alpha$-tocopheryl acetate $\left.\left(\mathrm{d}_{6}\right) / \mathrm{kg}\right)$ or $80 \mathrm{mg} / \mathrm{kg}$ (i.e. $40 \mathrm{mg} / \mathrm{kg}\left(\mathrm{d}_{3}\right)$ and $\left.40 \mathrm{mg} / \mathrm{kg}\left(\mathrm{d}_{6}\right)\right)$. Before pregnancy, the females were given non- ${ }^{2} \mathrm{H}$-labelled $\left(\mathrm{d}_{0}\right)$ vitamin $\mathrm{E}$ at $40 \mathrm{mg} / \mathrm{kg}$. Prepartum values were obtained on days 50 and 60 of pregnancy and postpartum results were obtained at days 1, 2, 4 and 5. Results were obtained from five dams at each of the six sampling times. For details of diets and procedures, see Table 1 and p. 456.

†Total vitamin $\mathrm{E}=$ non-2${ }^{2} \mathrm{H}$-labelled $\alpha$-tocopherol $\left(\mathrm{d}_{0}\right)+{ }^{2} \mathrm{H}$-labelled $(R R R)$ - $\alpha$-tocopherol $\left(\mathrm{d}_{3}\right)+{ }^{2} \mathrm{H}$-labelled all-rac- $\alpha$-tocopherol $\left(d_{6}\right)$.

‡The dose effect (40 v. $80 \mathrm{mg} / \mathrm{kg}$ ) was significant for all tissues except brain for the dams supplemented at $40 \mathrm{mg} / \mathrm{kg}$.

For the status effect (pre- $v$. postpartum), NS is given for $P>0.1$; the actual $P$ value is given for $0.05<P<0.1$.

The increase of dose $(40 v .80 \mathrm{mg} / \mathrm{kg})$ increased the tissue concentrations in all tissues except the brain. The increase in tissue concentration (from $41 \%$ in the lung to $65 \%$ in the adrenal gland) was less than proportional to the dose increase $(100 \%)$. There was no dose effect on the brain during pregnancy $(39.6$ (SD 4.13) v. 39.8 (SD $8.51) \mathrm{nmol} / \mathrm{g}$ for the 40 and $80 \mathrm{mg} / \mathrm{kg}$ dose respectively), but the dose did have a statistically significant, if modest, effect postpartum (increase of $21 \%$ ).

The influence of physiological status (two or six levels) was examined with a submodel that included dose and status. It was shown that the postpartum values were greater than the prepartum concentrations for five tissues (brain, kidney, leg muscle, spleen and plasma) and not significantly different for other tissues (adrenal gland, heart, liver, lung and ovary). The largest increase was observed for plasma $(+150$ and $+179 \%$ during postpartum for the 40 and $80 \mathrm{mg} / \mathrm{kg}$ doses respectively). Fig. 1 shows the influence of the status on tissue total vitamin E concentration for the $80 \mathrm{mg} / \mathrm{kg}$ dose.

Influence of tissue, dose and status on the (RRR)- $\alpha$-tocopherol:all-rac- $\alpha$-tocopherol ratio. Analysis of the $\mathrm{d}_{3}: \mathrm{d}_{6}$ ratio enables the relative bioavailability of natural $\left(\mathrm{d}_{3}\right) v$. synthetic $\left(\mathrm{d}_{6}\right)$ vitamin $E$ to be documented (see p. 457). The full GLM1 indicates that the tissues $(P<0 \cdot 001)$, dose $(P=0.026)$ and status $(P<0.001)$ had a significant effect on the $\mathrm{d}_{3}: \mathrm{d}_{6}$ ratio. However, the presence of a significant interaction (dose $\times$ status) and (status $\times$ tissue) led us to examine the response for each tissue level with a submodel that included dose and status as factors. Table 3 gives the $d_{3}: d_{6}$ ratio for the different tissues for the two dose levels and two main statuses.

The $d_{3}: d_{6}$ ratio (Table 3 ) was of the same order of magnitude for all tissues (1.64-1.90), i.e. a value higher than the current accepted value of $1 \cdot 36$. This ratio was systematically but marginally increased by the increase of the dose (from 1.8 to $5.8 \%$ ). It is noteworthy that the largest increase was observed for brain $(+5.8 \%, P=0.002)$. The ratio was higher in the postpartum period for all tissues, the increase being significant for brain, heart, liver, lung, spleen and plasma $(P<0.05)$, but not for the other tissues. The largest increases during postpartum were observed for liver $(+7.72 \%)$ spleen $(+19.7 \%)$ and plasma $(+13.4 \%)$. The increase for the other tissues was $<10 \%$.

A single regression between the $\mathrm{d}_{3}: \mathrm{d}_{6}$ ratio (as dependent variable) and the total tissue concentration of vitamin E $\left(d_{0}+d_{3}+d_{6}\right)$ was performed for each tissue, to explore the hypothesis that the $\mathrm{d}_{3}: \mathrm{d}_{6}$ ratio was concentrationdependent and that the relative efficiency of $d_{3}$ was greater than that of $\mathrm{d}_{6}$.

A positive and significant correlation between the two variables was found for all tissues. $R^{2}$ (the coefficient of determination, which expresses the percentage of variance explained by the regression model) was between $0 \cdot 19$ and 0.46 for all but one tissue (ovary). The intercept (i.e. the value of the $d_{3}: d_{6}$ ratio for a theoretical null 

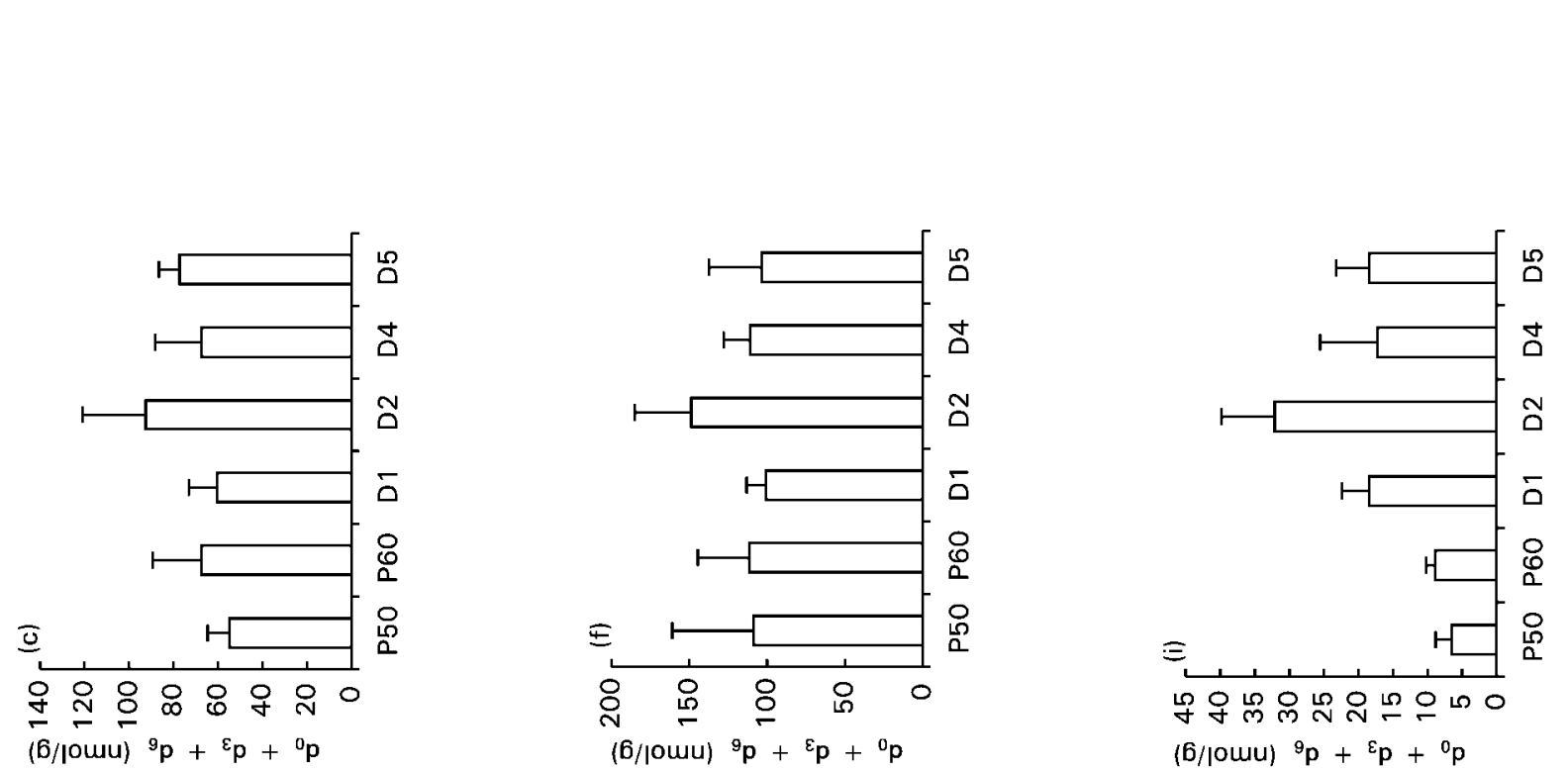

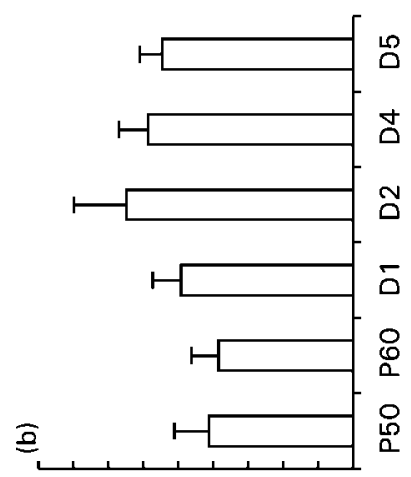
옹옹ㅇㅇㅇㅇㅇㅇㅇ유응 \{b//owu\} ${ }^{9} p+{ }^{\varepsilon} p+{ }^{0} p$

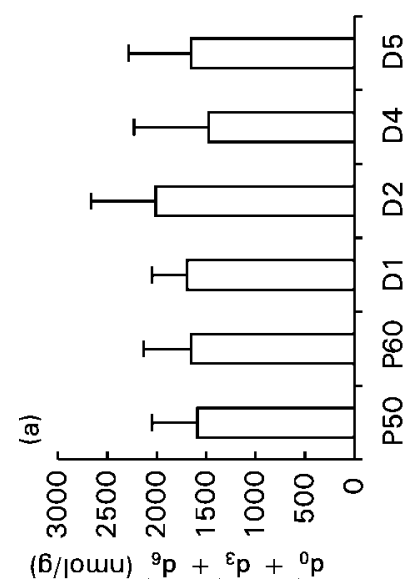

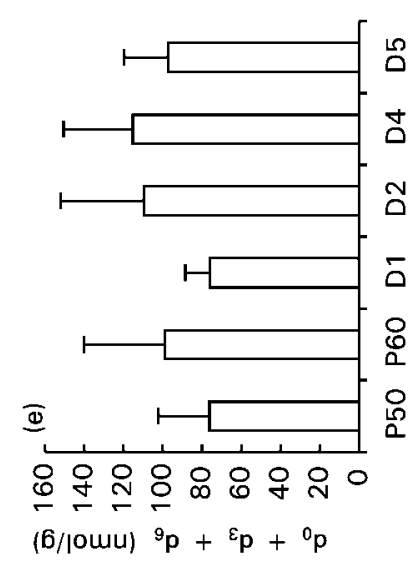

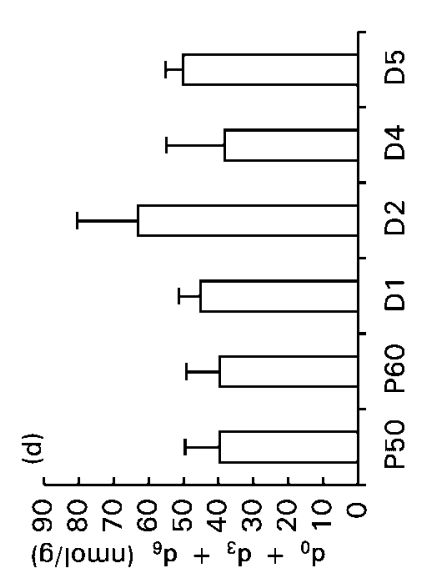

(6/|Ouu) ${ }^{9} p+{ }^{\varepsilon} p+{ }^{0} p$

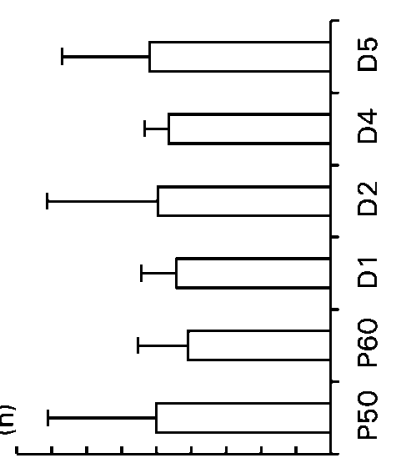

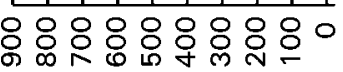

(b/|OUu) ${ }^{9} p+{ }^{\varepsilon} p+{ }^{0} p$

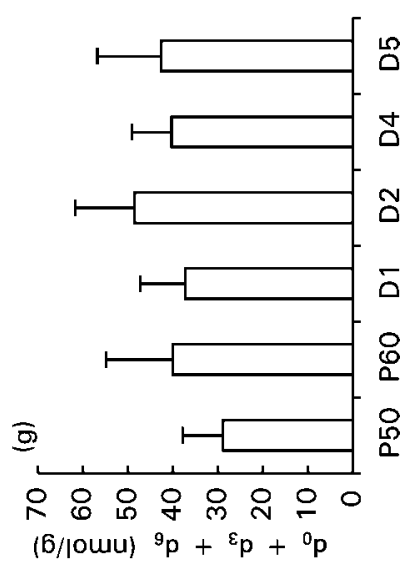


Table 3. Effect of vitamin $E$ dose $(40 \mathrm{v} .80 \mathrm{mg} / \mathrm{kg})$ on the $(R R R)$ - $\alpha$-tocopherol $\left(\mathrm{d}_{3}\right)$ :all-rac- $\alpha$-tocopherol $\left(\mathrm{d}_{6}\right)$ ratio in the tissues of guinea pig dams and their milk ${ }^{*} \dagger$

(Pooled mean values across pregnancy and/or postpartum and standard deviations)

\begin{tabular}{|c|c|c|c|c|c|}
\hline \multirow[b]{3}{*}{ Tissues } & \multicolumn{4}{|c|}{ Dose $(\mathrm{mg} / \mathrm{kg})$} & \multirow[b]{3}{*}{ Statistical significance of effect: $(P)$} \\
\hline & \multicolumn{2}{|c|}{40} & \multicolumn{2}{|c|}{80} & \\
\hline & Mean & SD & Mean & SD & \\
\hline Adrenal gland & 1.803 & 0.088 & 1.867 & $0 \cdot 131$ & 0.049 \\
\hline Brain & 1.899 & 0.111 & 2.009 & 0.126 & 0.002 \\
\hline Heart & 1.704 & 0.106 & 1.748 & 0.123 & 0.182 \\
\hline Kidney & 1.680 & 0.0695 & 1.700 & 0.0970 & 0.303 \\
\hline Liver & 1.709 & 0.1045 & 1.747 & 0.115 & 0.103 \\
\hline Lung & 1.800 & 0.0975 & 1.832 & 0.124 & 0.241 \\
\hline Leg muscle & 1.665 & 0.0807 & 1.729 & 0.123 & 0.040 \\
\hline Ovary & 1.778 & 0.136 & 1.813 & 0.109 & 0.230 \\
\hline Spleen & 1.639 & 0.190 & 1.709 & 0.187 & 0.033 \\
\hline Plasma & 1.801 & 0.143 & 1.851 & 0.162 & 0.112 \\
\hline Milk & 1.692 & 0.141 & 1.706 & 0.0951 & 0.717 \\
\hline
\end{tabular}

${ }^{\star}$ For details of diets and procedures, see Table 1 and p. 456.

† The dams received a daily equimolar supplement of $d_{3}$ and $d_{6}$ during the pregnancy and postpartum.

tissue concentration) was between 1.50 and $1 \cdot 73$. For all but one tissue (spleen) the lowest bound of the $95 \% \mathrm{CI}$ of the intercept was $>1.36$ (the current reference value for the relative potency ratio of $\mathrm{d}_{3}: \mathrm{d}_{6}$ ).

Relationship between plasma and tissue concentrations of vitamin E. Vitamin E monitoring is most easily done by measuring its concentration in plasma. A significant correlation between plasma concentration and the total tissue concentration $\left(\mathrm{d}_{0}+\mathrm{d}_{3}+\mathrm{d}_{6}\right)$ was found for all tissues, with the value of $R$ ranging from 0.32 (ovary) to 0.74 (brain).

Influence of tissue, dose and status on the ((RRR)$\alpha$-tocopherol + all-rac- $\alpha$-tocopherol):(unlabelled $\alpha$-tocopherol) ratio. The tissue ratio $\left(\mathrm{d}_{3}+\mathrm{d}_{6}\right): \mathrm{d}_{0}$ is an index of the rate of vitamin $\mathrm{E}$ equilibration. A high value would be expected for a tissue with a high turnover rate, because of the progressive replacement by $\mathrm{d}_{3}$ and $\mathrm{d}_{6}\left({ }^{2} \mathrm{H}\right.$-labelled vitamin administered during the study) of $\mathrm{d}_{0}$, the vitamin present before the beginning of pregnancy. The $\left(\mathrm{d}_{3}+\mathrm{d}_{6}\right): \mathrm{d}_{0}$ ratio for all but one tissue (brain) was largely $>1.0$. For the $40 \mathrm{mg} / \mathrm{kg}$ dose, the values were between 3.0 for muscle and 8.0-9.0 in plasma and liver. In contrast, the value was only $0.3-0.4$ in brain indicating that 'old' vitamin remained the dominant fraction in this tissue. This value was systematically increased with the highest tested dose and the values were higher postpartum than prepartum for all the tissues, especially for the highest tested dose (Table 4).

\section{Fetuses and pups}

Total vitamin $E$ concentrations (unlabelled $\alpha$-tocopherol $+(R R R)$ - $\alpha$-tocopherol + all-rac- $\alpha$-tocopherol).

For the total tissue vitamin $\mathrm{E}$ concentrations of fetal and neonatal guinea pigs there was no significant (dose $X$ status) and (dam $X$ tissue) interaction whereas the (dose $X$ tissue), (status $\times$ tissue) and (tissue $\times$ dose $\times$ status) interactions were highly significant $(P<0.001)$, which rendered interpretation of the main factors critical. Different submodels were therefore used to explore these aforementioned factors.

As with the dam, there were major differences between the vitamin $\mathrm{E}$ concentrations of the various tissues, the adrenal gland having the highest concentrations (Table 5). In contrast with the dam, the liver and spleen concentrations in the fetuses and pups were significantly higher $(P<0.05)$ than the concentrations in all the other tissues (brain, heart, kidney, lung, muscle and plasma).

The influence of dose and status was examined for each tissue with a submodel including dose, status and interaction (dose $\times$ status). The dose factor had a significant effect on all but one tissue (plasma), the highest dose leading to the highest tissue concentrations with a relative increase of about 22 to $47 \%$ (see Table 5). When compared with maternal tissue, the dose effect was more limited for the fetus (pups) with the notable exception of the brain, which displayed a relative increase of $36 \%$ (v. $20 \%$ in the dam).

A significant and positive correlation between tissue concentrations in dam and fetus (pups) was observed for all the tissues. The mean placenta concentrations at days 50 and 60 of pregnancy were 99 (SD 37) and 166 (SD $80) \mathrm{nmol} / \mathrm{g}$ for the 40 and $80 \mathrm{mg} / \mathrm{kg}$ doses respectively, indicating a large increase $(+68 \%)$ due to the dose.

The status effect (six levels) was highly significant $(P<0.001)$, with the same pattern for all but one tissue (liver). The tissue concentrations were lowest during pregnancy (but higher at day 60 than at day 50). A large increase was then immediately observed after parturition, the tissue concentrations reaching a maximum value at day 2 postpartum. All the tissue concentrations decreased after day 2 with both dose levels. In contrast, the maximum liver concentrations were observed during pregnancy, after which the hepatic concentrations decreased progressively during the postpartum period to reach a minimum value at day 5 postpartum. Fig. 2 shows the influence of the different sampling times on fetal (pups) tissue concentrations for the two dose levels. 
Table 4. Effect of vitamin $\mathrm{E}$ dose $(40 \mathrm{v} .80 \mathrm{mg} / \mathrm{kg})$ and status (pre- $v$. postpartum), on ((RRR)$\alpha$-tocopherol $\left(\mathrm{d}_{3}\right)+$ all-rac- $\alpha$-tocopherol $\left.\left(\mathrm{d}_{6}\right)\right) / \alpha$-tocopherol $\left(\mathrm{d}_{0}\right)$ in guinea pig dams ${ }^{*} \dagger$

(Mean values and standard deviations for five guinea pigs per group)

\begin{tabular}{|c|c|c|c|c|c|c|c|c|}
\hline \multirow[b]{4}{*}{ Tissue† } & \multicolumn{8}{|c|}{ Dose $(\mathrm{mg} / \mathrm{kg})$} \\
\hline & \multicolumn{4}{|c|}{40} & \multicolumn{4}{|c|}{80} \\
\hline & \multicolumn{2}{|c|}{ Prepartum† } & \multicolumn{2}{|c|}{ Postpartum† } & \multicolumn{2}{|c|}{ Prepartum† } & \multicolumn{2}{|c|}{ Postpartum† } \\
\hline & Mean & SD & Mean & SD & Mean & $\overline{S D}$ & Mean & SD \\
\hline Adrenal gland & $5 \cdot 7$ & $2 \cdot 0$ & $6 \cdot 6$ & $2 \cdot 7$ & $10 \cdot 4$ & 3.2 & 16.9 & $2 \cdot 8$ \\
\hline Brain & 0.29 & 0.105 & 0.43 & 0.18 & 0.52 & 0.26 & 1.31 & 0.32 \\
\hline Heart & $6 \cdot 0$ & 1.9 & $6 \cdot 8$ & 1.9 & $9 \cdot 8$ & 3.4 & $15 \cdot 6$ & 1.6 \\
\hline Kidney & $5 \cdot 3$ & 1.9 & $7 \cdot 3$ & 4.4 & $9 \cdot 3$ & 3.5 & $16 \cdot 3$ & 2.9 \\
\hline Liver & 8.6 & $2 \cdot 1$ & 9.0 & $2 \cdot 4$ & $12 \cdot 2$ & $5 \cdot 0$ & $18 \cdot 6$ & $2 \cdot 9$ \\
\hline Lung & $6 \cdot 8$ & 1.9 & $7 \cdot 1$ & $2 \cdot 0$ & 10.6 & 3.4 & $16 \cdot 3$ & 3.0 \\
\hline Leg muscle & 2.9 & $1 \cdot 1$ & 3.7 & 1.8 & 5.5 & $3 \cdot 0$ & 11.4 & 1.8 \\
\hline Ovary & $6 \cdot 7$ & $2 \cdot 1$ & $7 \cdot 1$ & $2 \cdot 3$ & 11.3 & $4 \cdot 0$ & $17 \cdot 8$ & $2 \cdot 3$ \\
\hline Spleen & $8 \cdot 1$ & $2 \cdot 1$ & 8.9 & 2.0 & 12.0 & 4.7 & $18 \cdot 2$ & 4.0 \\
\hline Plasma & $9 \cdot 0$ & $2 \cdot 3$ & $8 \cdot 3$ & $2 \cdot 3$ & $12 \cdot 2$ & 5.5 & $17 \cdot \overline{8}$ & 3.4 \\
\hline Milk & & & $5 \cdot 8$ & 1.7 & & & 11.9 & 2.5 \\
\hline
\end{tabular}

* Vitamin $\mathrm{E}$ was administered as ${ }^{2} \mathrm{H}$-labelled vitamin $\mathrm{E}$ from day 1 of pregnancy and progressively replaced $\mathrm{d}_{0}$, the non- ${ }^{2} \mathrm{H}$-labelled vitamin $\mathrm{E}$ present before pregnancy. For details of diets and procedures, see Table 1 and p. 456.

†Prepartum values were obtained at days 50 and 60 and postpartum values at days 1, 2, 4 and 5 (five dams at each sampling time).

Influence of tissue, dose and status on the (RRR)- $\alpha$-tocopherol: all-rac- $\alpha$-tocopherol ratio. Despite some significant interactions and significant effects of status, dose and tissue, shown by different statistical models, the $\mathrm{d}_{3}: \mathrm{d}_{6}$ ratio was of the same order of magnitude across tissue, dose and status. The $99 \%$ CI was calculated for each tissue (Table 6). Table 6 shows that the lower bound of the $99 \% \mathrm{CI}$ is much greater than 1.36 (the current accepted biopotency reference value). The $\mathrm{d}_{3}: \mathrm{d}_{6}$ ratio for all the tissues, except the adrenal gland and brain, was higher in the fetus (pups) than in the dams, the difference being highly significant $(P<0.001)$ for most tissues.

The $\mathrm{d}_{3}: \mathrm{d}_{6}$ ratios in fetuses and pups were, as with the mothers, positively correlated with the total vitamin E concentrations for all tissues. The correlation was significant $(P<0.01)$ for all but three tissues (liver, placenta and plasma).

Influence of tissue dose and status on the ((RRR)$\alpha$-tocopherol + all-rac- $\alpha$-tocopherol):(unlabelled $\alpha$-tocopherol) ratio. Despite some significant interactions and some significant effects, the $\left(\mathrm{d}_{3}+\mathrm{d}_{6}\right): \mathrm{d}_{0}$ ratio was of the same order of magnitude for all tissues and before and after parturition for the lowest dose. In contrast, the postpartum values for the highest dose $(80 \mathrm{mg} / \mathrm{kg})$ were much higher than those prepartum (Table 7). The brain merits attention, as the ratio in the fetuses (pups) was 12-16-fold higher than in the mothers.

\section{Milk concentrations}

Milk concentrations were analysed with a model including dose, status (four levels) and (dose $\times$ status) interaction (NS). The same trend as for the tissues was observed with an increase of milk concentration for day 1 and day 2 , then a decrease at day 4 and 5 . This pattern was observed for the two dose levels. The maximum milk concentrations (day 2) were $5.3(\mathrm{SD} 1.2)$ and $7.3(\mathrm{SD} 2 \cdot 2) \mathrm{nmol} /$ $\mathrm{ml}$ for 40 and $80 \mathrm{mg} / \mathrm{kg}$ respectively. Influence of dose on $\mathrm{d}_{3}: \mathrm{d}_{6}$ ratio and $\left(\mathrm{d}_{3}+\mathrm{d}_{6}: \mathrm{d}_{0}\right)$ ratio are presented in Tables 3

Table 5. Effect of maternal vitamin $\mathrm{E}$ dose (40 v. $80 \mathrm{mg} / \mathrm{kg}$ ) on total vitamin $\mathrm{E}$ concentrations $(\mathrm{nmol} / \mathrm{g})$ in tissues of fetal and neonatal guinea pigs ${ }^{*} \dagger$

(Mean values and standard deviations for six statuses at two dose levels $\ddagger$ )

\begin{tabular}{lrrrrr}
\hline \multirow{2}{*}{ Tissue } & \multicolumn{4}{c}{ Dose $(\mathrm{mg} / \mathrm{kg}) \S$} \\
\cline { 2 - 5 } & \multicolumn{2}{c}{40} & & \multicolumn{2}{c}{80} \\
\cline { 2 - 3 } \cline { 5 - 6 } & Mean & SD & & Mean & SD \\
\hline Adrenal gland & 496 & 235 & 733 & 316 \\
Brain & 30 & 14 & 41 & 18 \\
Heart & 60 & 16 & 77 & 18 \\
Kidney & 33 & 9 & 43 & 8 \\
Liver & 127 & 55 & 168 & 69 \\
Lung & 69 & 29 & 93 & 36 \\
Spleen & 107 & 49 & 131 & 37 \\
Leg muscle & 30 & 10 & 37 & 10 \\
Plasma & 25 & 13 & 29 & 13 \\
Milk & 4 & 1 & 7 & 2 \\
\hline
\end{tabular}

* At day 1 of assumed pregnancy, females were switched from non- ${ }^{2} \mathrm{H}$-labelled vitamin $\mathrm{E}$ ( $\alpha$-tocopherol $40 \mathrm{mg} / \mathrm{kg}$ diet) to ${ }^{2} \mathrm{H}$-labelled vitamin $\mathrm{E}$ at two dose levels: (1) $20 \mathrm{mg}$ $(R R R)$ - $\alpha$-tocopheryl acetate $\left(\mathrm{d}_{3}\right)+20 \mathrm{mg}$ all-rac- $\alpha$-tocopheryl acetate $\left(d_{6}\right) / \mathrm{kg}$; or (2) $40 \mathrm{mg}\left(\mathrm{d}_{3}\right) / \mathrm{kg}+40 \mathrm{mg}\left(\mathrm{d}_{0}\right) / \mathrm{kg}$. For details of diets and procedures, see Table 1 and $p$. 456.

†Total vitamin $\mathrm{E}=$ non- ${ }^{2} \mathrm{H}$-labelled $\alpha$-tocopherol present before start of pregnancy $\left(\mathrm{d}_{0}\right)+{ }^{2} \mathrm{H}$-labelled- $\alpha$-tocopheryl acetate $\left(\mathrm{d}_{3}\right)+{ }^{2} \mathrm{H}$-labelled all-rac- $\alpha$-tocopheryl acetate $\left(\mathrm{d}_{6}\right)$.

‡Pregnancy at days 50 and 60 and days 1,2, 4 and 5 postpartum.

$\S$ The dose effect was significant $(P<0.05)$ for all tissues except plasma. 


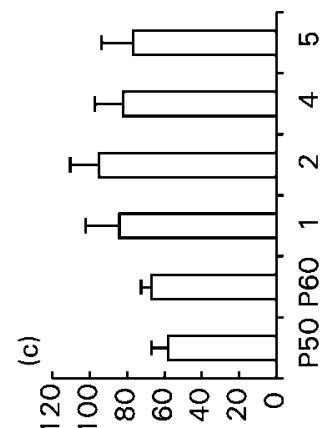

(6/ןouu) ${ }^{9} p+{ }^{\varepsilon} p+{ }^{0} p$

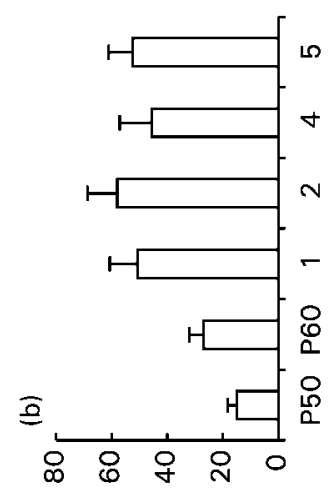

(6/ןouu) ${ }^{9} p+{ }^{\varepsilon} p+{ }^{0} p$
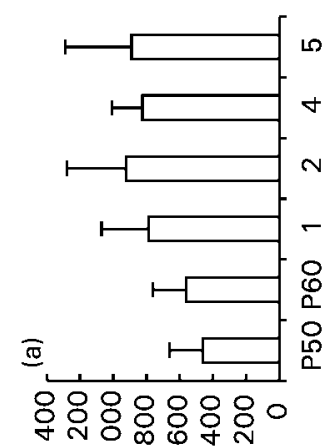

((6/ןouu) ${ }^{9 p}+{ }^{\varepsilon} p+{ }^{0 p}$
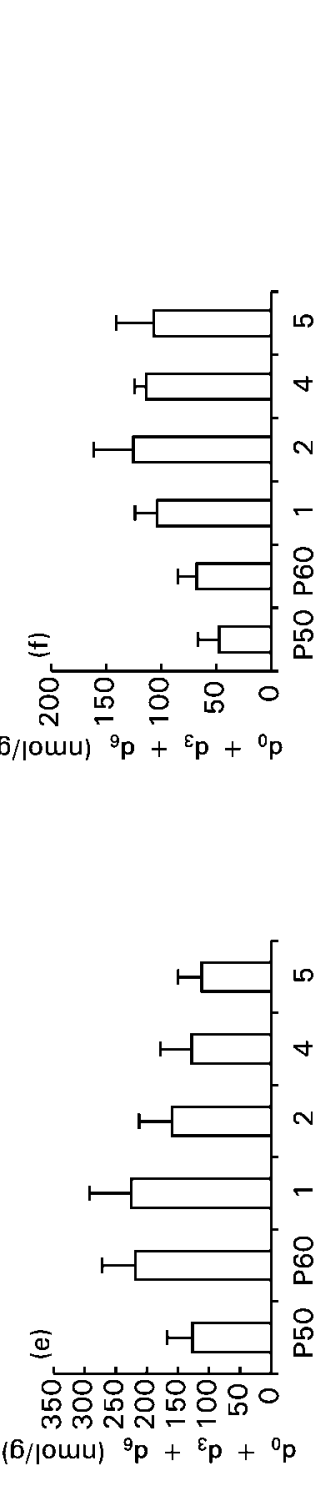

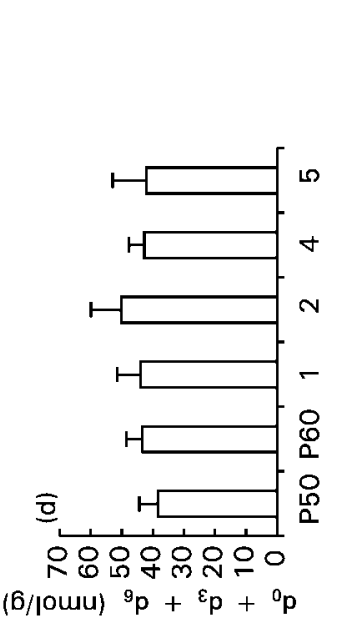

욜

可

更

ฮ ర్ల

후요

बิ휴

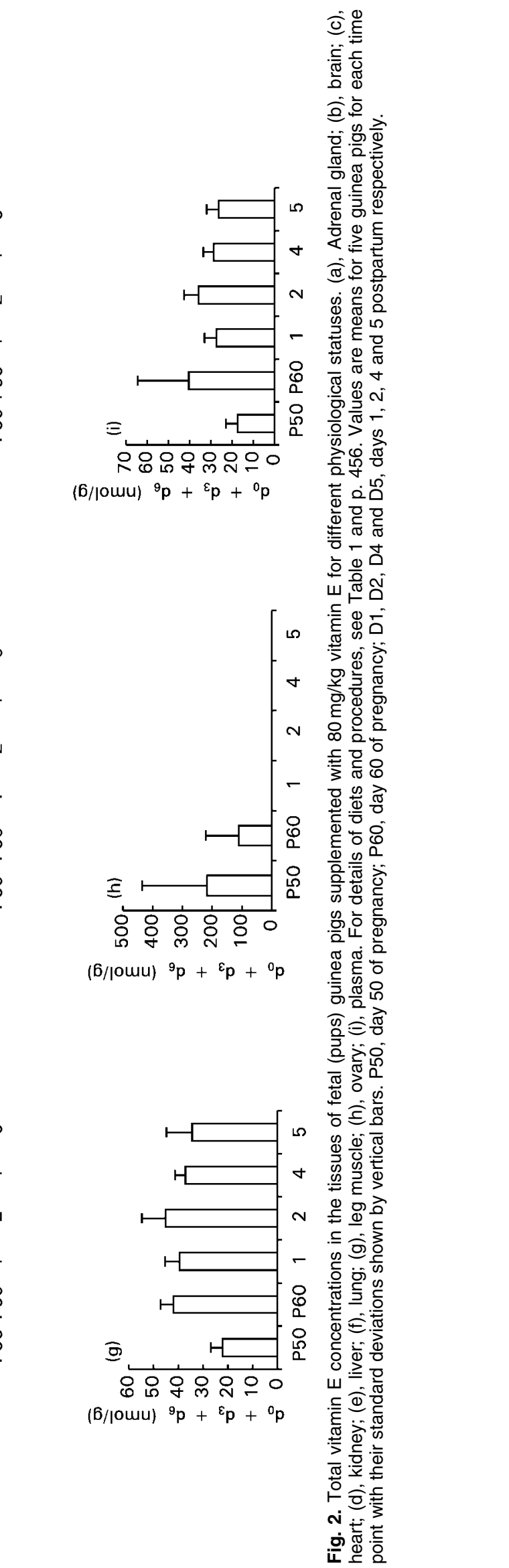

(6/ןouu) ${ }^{9} p+{ }^{\varepsilon} p+{ }^{0} p$ 
Table 6. Effect of vitamin $\mathrm{E}$ dose $(40 \mathrm{v}$. $80 \mathrm{mg} / \mathrm{kg})$ on the $(R R R)$ - $\alpha$-tocopherol to $\left(d_{3}\right)$ :all-rac- $\alpha$ tocopherol $\left(d_{6}\right)$ ratio in the tissues of guinea pig fetuses and pups*

(Mean values and $95 \%$ confidence intervals for six statuses at two dose levels)

\begin{tabular}{lcc}
\hline Tissue & Mean & $99 \% \mathrm{Cl}$ \\
\hline Adrenal gland & 1.78 & $1.75,1.81$ \\
Brain & 1.89 & $1.91,1.87$ \\
Heart & 1.88 & $1.85,1.90$ \\
Kidney & 1.81 & $1.78,1.83$ \\
Liver & 1.78 & $1.74,1.78$ \\
Lung & 1.89 & $1.87,1.91$ \\
Leg muscle & 1.82 & $1.81,1.85$ \\
Placenta & 1.62 & $1.59,1.66$ \\
Spleen & 1.80 & $1.78,1.82$ \\
Plasma & 1.85 & $1.83,1.88$ \\
Milk & 1.70 & $165,1.75$
\end{tabular}

${ }^{*}$ For details of diets and procedures, see Table 1 and p. 456.

†Pregnancy at days 50 and 60 and days 1, 2, 4 and 5 postpartum.

and 4 respectively. Mean overall milk $\mathrm{d}_{3}: \mathrm{d}_{6}$ ratios over the lactation period were 1.69 (SD 0.14) and 1.71 (SD 0.09) for the 40 and $80 \mathrm{mg} / \mathrm{kg}$ dietary vitamin E respectively.

\section{Discussion}

One of the goals of the present study was to evaluate the hypothesis that tissue $\alpha$-tocopherol concentrations after a continuous oral dosing of an equimolar 1:1 mixture of all$r a c-\alpha$-tocopheryl acetate and $(R R R)-\alpha$-tocopheryl acetate reflect the activity ratio of 1.36:1.00 for these forms respectively (United States Pharmacopeia, 1985). For all guinea pigs studied, natural vitamin $\mathrm{E}\left(\mathrm{d}_{3}\right)$ was more bioavailable
$(P<0 \cdot 05)$ as shown by a greater $\mathrm{d}_{3}: \mathrm{d}_{6}$ ratio for all tissues analysed (Tables 3 and 6 ). Likewise, the $\mathrm{d}_{3}: \mathrm{d}_{6}$ ratios were found to be substantially greater than the currently accepted biological potencies of 1.36:1.00 ((RRR)- $\alpha$-tocopheryl acetate:all-rac- $\alpha$-tocopheryl acetate).

For the two $\alpha$-tocopherol dose levels (40 or $80 \mathrm{mg} / \mathrm{kg}$ ) for dam tissues, the relative bioavailability (natural:synthetic $\alpha$-tocopherol) was on average 1.77:1.00, and across fetal and neonatal tissues the relative bioavailability was on average 1.81:1.00. The highest ratios were for brain, adrenal gland, plasma, lung and ovary, with lowest ratios for spleen, muscle, kidney and heart. In an earlier study with only one level of dietary vitamin $\mathrm{E}$, maternal tissues showed on average a ratio of 1.82:1.00 $\left(\mathrm{d}_{3}: \mathrm{d}_{6}\right)$ and the relative bioavailability $\left(\mathrm{d}_{3}: \mathrm{d}_{6}\right)$ across fetal and neonatal tissues was on average 1.85:1.00 (Hidiroglou et al. 2001).

Biodiscrimination in favour of $\mathrm{d}_{3}$ using the isotopic technique for the guinea pig as a model has also been reported recently in vitamin $\mathrm{E}$ studies with human subjects (Acuff et al. 1994; Burton et al. 1998). Burton et al. (1998), using ${ }^{2} \mathrm{H}$-labelled vitamin $\mathrm{E}$ compounds (natural $\left(\mathrm{d}_{3}\right)$ and synthetic $\left(d_{6}\right)$ ) in human subjects at different oral dose levels, showed that plasma and lipoprotein $\mathrm{d}_{3}: \mathrm{d}_{6}$ ratios approached $2 \cdot 00$, in favour of the natural form. In a study with human subjects, Acuff et al. (1998), as well utilising ${ }^{2} \mathrm{H}$-labelled vitamin $\mathrm{E}$ compounds, oral ingestion with equimolar amounts of $\mathrm{d}_{3}$ and $\mathrm{d}_{6}$ demonstrated that the bioavailability (based on blood vitamin $E$ concentrations) was nearly 2-fold higher in favour of the natural form. Therefore, the tissue $d_{3}: d_{6}$ ratios from the present experiment and a previous study (Hidiroglou et al. 2001) suggest that the guinea pig represents an excellent rodent model for vitamin $\mathrm{E}$ bioavailability issues related to man. The mechanism involved in the extent of biodiscrimination of the different forms of vitamin $\mathrm{E}$ has recently become known. According to Traber et al. (1996), biodiscrimination between $\mathrm{d}_{3}$ and $\mathrm{d}_{6}$ occurs postabsorptively. Accumulating

Table 7. Effect of vitamin E dose $(40 v .80 \mathrm{mg} / \mathrm{kg})$ and status (pre- $v$. postpartum) on the $\left((R R R)\right.$ - $\alpha$-tocopherol $\left(\mathrm{d}_{3}\right)+$ all-rac- $\alpha$-tocopherol $\left.\left(\mathrm{d}_{6}\right)\right): \alpha$-tocopherol $\left(\mathrm{d}_{0}\right)$ ratio in guinea pig fetuses and pups*

(Mean values)

\begin{tabular}{|c|c|c|c|c|}
\hline \multirow[b]{3}{*}{ Tissue } & \multicolumn{4}{|c|}{ Dose $(\mathrm{mg} / \mathrm{kg})$} \\
\hline & \multicolumn{2}{|c|}{40} & \multicolumn{2}{|c|}{80} \\
\hline & Prepartum† & Postpartum† & Prepartum† & Postpartum† \\
\hline Adrenal gland & $6 \cdot 0$ & $6 \cdot 9$ & $9 \cdot 7$ & $17 \cdot 8$ \\
\hline Brain & 5.9 & 5.5 & $8 \cdot 8$ & $14 \cdot 6$ \\
\hline Heart & $6 \cdot 9$ & $7 \cdot 3$ & $10 \cdot 6$ & $17 \cdot 4$ \\
\hline Kidney & 7.5 & $7 \cdot 8$ & $11 \cdot 1$ & $18 \cdot 6$ \\
\hline Liver & $8 \cdot 4$ & $8 \cdot 6$ & $12 \cdot 3$ & $20 \cdot 2$ \\
\hline Lung & $7 \cdot 3$ & $9 \cdot 6$ & $11 \cdot 2$ & 7.9 \\
\hline Leg muscle & $7 \cdot 3$ & $7 \cdot 0$ & 11.2 & $18 \cdot 3$ \\
\hline Spleen & 8.5 & $8 \cdot 3$ & $12 \cdot 4$ & $17 \cdot 7$ \\
\hline Plasma & $7 \cdot 9$ & $7 \cdot 6$ & $11 \cdot 2$ & $17 \cdot 3$ \\
\hline Placenta & $9 \cdot 1$ & - & $12 \cdot 3$ & \\
\hline
\end{tabular}

*Vitamin $\mathrm{E}$ was administered as ${ }^{2} \mathrm{H}$-labelled vitamin $\mathrm{E}$ from day 1 of pregnancy and progessively replaced $\mathrm{d}_{0}$, the non- ${ }^{2} \mathrm{H}$-labelled vitamin $\mathrm{E}$ present before pregnancy. For details of diets and procedures, see Table 1 and p. 456.

†Prepartum values were obtained at days 50 and 60 and postpartum values at days 1, 2, 4 and 5 (five dams at each sampling time). 
evidence suggests that the liver is probably the mechanism for biodiscrimination of vitamin $E$ isomers, involving a specific $\alpha$-tocopherol binding transfer protein, with a preferential enrichment of VLDL with $R R R$ - $\alpha$-tocopherol and subsequent release into circulation (Traber et al. 1996).

The mechanisms and interactions among various stereoisomers of $\alpha$-tocopherol and their influence on tissue $R R R$ $\alpha$-tocopherol until recently was limited. However, a growing body of evidence from studies with various species including rats (Weiser \& Vecchi, 1981; Leth \& Sondergaard, 1983; Ogihara et al. 1985; Ingold et al. 1987; Behrens \& Madere, 1991; Weiser et al. 1996), seals (Engelhardt, 1977), fish (Hung et al. 1982), sheep (Hidiroglou et al. 1988b, 1992), cattle (Hidiroglou et al. 1988a) and pigs (Chung et al. 1992; Mahan et al. 2000) indicated that the uptake of isomers of the natural configuration $2 R$ was significantly higher than that of the configuration $2 S$, though the extent of discrimination between the $2 R$ and $2 S$ isomers varied somewhat among species.

Using rats, Behrens \& Madere (1991) demonstrated that dietary level of vitamin $\mathrm{E}$ had an impact on the response in the extent of biodiscrimination between $(R R R)$ - $\alpha$-tocopheryl acetate and all-rac- $\alpha$-tocopheryl acetate. These investigators demonstrated that feeding equimolar amounts of $(R R R)-\alpha-$ tocopheryl acetate and all-rac- $\alpha$-tocopheryl acetate (each at $35 \mathrm{mg} / \mathrm{kg}$ diet, low dose), resulted in a tissue preference for the natural diastereoisomer, $(R R R)$ - $\alpha$-tocopherol, over the all-rac- $\alpha$-tocopherol form in a ratio ranging from 1.0 to 1.5 ; the exception was in erythrocytes, which showed a 4fold increase in the values of the ratio. For the group supplemented with $200 \mathrm{mg}$ either $(R R R)$ - $\alpha$-tocopheryl acetate or all-rac- $\alpha$-tocopheryl acetate $/ \mathrm{kg}$ diet, no further discrimination in favour of $(R R R)$ - $\alpha$-tocopherol over all-rac $\alpha$-tocopherol was observed in the tissues. These investigators suggest that at higher dietary levels $(200 \mathrm{mg} / \mathrm{kg}$ diet $)$ there is lack of further biodiscrimination between forms. Administration of $(R R R)$ - $\alpha$-tocopherol at relatively high concentrations could saturate any receptor and/or specific proteins and make the binding of other stereoisomers difficult so that discrimination cannot be detected. In our present study, the $\mathrm{d}_{3}: \mathrm{d}_{6}$ ratio was marginally increased (1.8 to $3.8 \%$ ) by the higher dose The largest increase was observed for the brain $(5.8 \%)$. The results of the present study are in agreement with those of Behrens \& Madere (1991), who suggested a lack of further biodiscrimination between forms at higher levels of vitamin E supplementation.

\section{Vitamin E status in fetal and/or neonatal guinea pigs}

The extent of placental and mammary gland transfer of vitamin $\mathrm{E}$ was evaluated in guinea pigs following a continual oral dosing with ${ }^{2} \mathrm{H}$-labelled $\alpha$-tocopherol compounds at two levels to pregnant and nursing dams. Vitamin E analysis from fetal and neonatal tissues supports the hypothesis of a substantial transfer of ${ }^{2} \mathrm{H}$-labelled $\alpha$-tocopherol compounds across the placenta and through the mammary gland. In contrast with other species including pigs, rats, cattle and sheep (Njeru et al. 1994), efficiency in the transfer of vitamin $\mathrm{E}$ across the placenta seems greater in the guinea pig. However, we cannot exclude the possibility of a lower clearance rate, which could partially explain the higher vitamin $\mathrm{E}$ concentration in the guinea pig. Vitamin E tissue concentrations in descending order were: adrenal gland, liver, spleen, lung, heart, kidney, brain, muscle and plasma. The higher dose level of dietary vitamin $\mathrm{E}(80 \mathrm{mg} / \mathrm{kg})$ significantly increased all tissue levels, except plasma, from 22 to $47 \%$ (Table 5). The tissue $\left(d_{3}+d_{6}\right): d_{0}$ ratio is an index of vitamin $E$ equilibrium: a high ratio indicates tissues with a high turnover. Except for brain, the ratio was considerably higher than the value of 1.0 in dams (Table 4). The ratio in the brains of the fetuses and pups was 12-16-fold greater than in the mothers. In the pregnant and lactating dams, the $\mathrm{d}_{3}+\mathrm{d}_{6}: \mathrm{d}_{0}$ ratio in the brain was weak, suggesting a very slow turnover of vitamin E. Indeed, this could be related to the lack of permeability of vitamin $\mathrm{E}$ across the blood brain barrier (Fand \& McNally, 1981). This probably explains the lack of dose effect of vitamin $\mathrm{E}$ in total vitamin $\mathrm{E}$ concentrations in the dams' brains. In contrast, vitamin $E$ ratios in the brains of fetuses and pups $\left(d_{3}+d_{6}: d_{0}\right)$ suggest a substantial transfer of vitamin E. This phenomenon might be related to the fact that during ontogenesis the blood-brain barrier is not as functional, thus allowing the transfer of vitamin E. Similarly, Zhang Zong-hao et al. (1987) observed that in newborn rat pups, vitamin $\mathrm{E}$ is more permeable across the blood-brain barrier than for the corresponding dams.

Colostrum contains the highest concentration of vitamin E of the milk curve (Kelly, 1993; Njeru et al. 1994) and subsequently declines with maturation of the milk. Our present results from milk tend to support this, although the decline in milk vitamin $\mathrm{E}$ values from day 2 to 5 did not reach statistical significance $(P=0.05)$ The maximum vitamin $\mathrm{E}$ concentration (day 2) in milk was greater for the higher supplemented animals, $7.3 v .5 \cdot 3 \mathrm{nmol} / \mathrm{g}$ respectively. In sheep, colostral milk responded linearly to graded supplemented levels of vitamin E (Njeru et al. 1994). Placental and milk $\mathrm{d}_{3}: \mathrm{d}_{6}$ ratios suggest that no further biodiscrimination occurred between the two vitamin E sources beyond that observed for maternal tissue $\mathrm{d}_{3}: \mathrm{d}_{6}$ ratios.

Increased plasma $\alpha$-tocopherol levels in neonates is attributed to both the release of liver $\alpha$-tocopherol stores (Kelly et al. 1992) and high $\alpha$-tocopherol found in colostrum (Ostrea et al. 1986). In a guinea pig study, the marked postnatal decline in $\alpha$-tocopherol observed from the liver suggests that the liver acts as a reservoir releasing $\alpha$-tocopherol into the blood immediately following birth (Kelly et al. 1992). This finding has been observed from previous findings in other species, including pigs (Schlotke et al. 1978) and rats (Butcher \& Roberts, 1981). Our present results from pups on the time profile (days 1-5) of hepatic vitamin E status lends further support to this concept. The use of the two isotopically labelled forms of the vitamin not only distinguishes between the two forms, but also distinguishes vitamin $\mathrm{E}$ ingested during pregnancy $\left(\mathrm{d}_{3}\right.$ and $\left.\mathrm{d}_{6}\right)$ from pre-pregnancy body stores $\left(\mathrm{d}_{0}, \alpha\right.$-tocopherol). In guinea pigs, vitamin $\mathrm{E}$ concentrations in a limited number of tissues examined were found to be as high or higher than those in corresponding dams (Kelly et al. 1992). Our present vitamin E results, obtained from multiple selection of fetal tissues at days 50 and 60 of gestation, are in agreement with 
Kelly et al. (1992), who demonstrated, in late-term fetal guinea pigs, that $\alpha$-tocopherol concentrations were nearing or greater than levels that were reported in corresponding maternal guinea pigs.

In summary, the results show that natural form of the vitamin is much better utilised, compared with the rac form, than has been generally thought. The guinea pig results provide further evidence that the current accepted biological activities of 1·36:1.00 (natural $\alpha$-tocopherol:synthetic $\alpha$-tocopherol) underestimates the relative bioavailability between the two principle commercial sources of $\alpha$-tocopherol. Fetal and neonatal guinea pig tissue $\alpha$-tocopherol levels were found to be near or higher than corresponding dams.

\section{Acknowledgements}

We extend our sincere gratitude to Eastman Chemicals for the generous provision of ${ }^{2} \mathrm{H}$-labelled $\alpha$-tocopherol compounds. The authors are very grateful to Dr Luszytk at the National Research Council for access to the GC-MS. The authors also extend their appreciation to the animal care staff of the Animal Resource Division for the care and well being of the guinea pigs. The constructive comments and suggestions of Drs Scoggan and Peace are greatly appreciated.

\section{References}

Acuff RV, Thedford SS, Hidiroglou NN, Papas AM \& Odom TA Jr (1994) Relative bioavailability of RRR and all-rac-alpha-tocopheryl acetate in humans: studies using deuterated compounds. American Journal of Clinical Nutrition 60, 397-402.

Behrens W \& Madere R (1991) Tissue discrimination between dietary RRR-alpha tocopherol and all-rac-alpha tocopherols in rats. Journal of Nutrition 121, 454-459.

Burton GW \& Ingold KU (1993) Biokinetics of vitamin E using deuterated tocopherols. In Vitamin $E$ in Health and Disease, pp. 329-344 [L Packer and J Fuchs, editors]. New York: Marcel Dekker.

Burton GW, Traber MG, Acuff RV, Walters DN, Kayden H, Hughes L \& Ingold KU (1998) Human plasma and tissue alpha tocopherol concentrations in response to supplementation with deuterated natural and synthetic vitamin E. American Journal of Clinical Nutrition 67, 669-684.

Burton GW, Webb A \& Ingold KU (1985) Rapid lipid extraction with SDS for vitamin E/lipid ratios. Lipids 20, 29-39.

Butcher JR \& Roberts RJ (1981) Alpha-tocopherol (vitamin E) content of lung, liver and blood in the newborn rat and human infant. Influence of hyperoxia. Pediatrics 98, 806-811.

Canadian Council of Animal Care (1993) Guide to the Care and Use of Experimental Animals, 2nd ed. [ED Olfert, BM Cross and AA McWilliam, editors]. Ottawa, Ontario, Canada: Bradda Publishing.

Chiswick ML, Johnson M \& Toner N (1982) Vitamin E and intravascular hemorrhage in the newborn. Annals New York Academy of Science 393, 109-118.

Chung YK, Mahan DC \& Lepine AJ (1992) Efficacy of dietary D-alpha-tocopherol and DL-alpha-tocopheryl acetate for weanling pigs. Journal of Animal Science 70, 2485-2492.

Ehrenkranz RA, Ablow RC \& Warshaw JB (1979) Prevention of bronchopulmonary dysplasia with vitamin $\mathrm{E}$ administration during the acute stages of respiratory distress syndrome. Journal of Pediatrics 95, 873-885.

Ehrenkranz RA, Bonta BW, Ablovi RC \& Warshaw JB (1978) Amelioration of bronchopulmonary dysplasia after vitamin $\mathrm{E}$ administration: a preliminary report. New England Journal of Medicine 299, 564-570.

Engelhardt ER (1977) Plasma and tissue levels of dietary radiotocopherols in the Harp Seal (Phoca Groenlandica). Canadian Journal of Physiology and Pharmacology 55, 601-608.

Fand I \& McNally WP (1981) Whole body localization of ${ }^{14} \mathrm{C}$-tocopheryl acetate in the rat following oral adminstration. Archives International Pharmacodynamics Therapeutics 250, 4-17.

Health Canada (1995) Guidelines for the composition and clinical testing of formulas for preterm infants. Report of an ad hoc Expert Consultation, pp. 1-78. Ottawa, Ontario, Canada: Minister of Supply and Services Canada.

Hidiroglou N, Laflamme L \& McDowell LR (1988a) Blood plasma and tissue concentrations of vitamin $\mathrm{E}$ in beef cattle as influenced by supplementation of various tocopherol compounds. Journal of Animal Science 66, 3227-3234.

Hidiroglou N, McDowell LR, Papas AM, Antapli M \& Wikinson NS (1992) Bioavailability of vitamin E compounds in lambs. Journal of Animal Science 70, 2556-2561.

Hidiroglou N, McDowell LR \& Pastrana R (1988b) Bioavailability of various vitamin $\mathrm{E}$ compounds in sheep. International Journal of Vitamin Nutrition Research 58, 189-197.

Hidiroglou N, Madere R \& McDowell L (2001) Maternal transfer of vitamin $\mathrm{E}$ to fetal and neonatal guinea pigs utilizing a stable isotopic technique. Nutrition Research 21, 771-783.

Hung SSO, Moon TW, Hilton JW \& Slinger SJ (1982) Uptake, transport and distribution of DL-alpha-tocopheryl acetate compared to D-alpha tocopherol in rainbow trout. Journal of Nutrition 112, 1590-1599.

Ingold KU, Burton GW, Foster DO, Hughes L, Lindsay DA \& Webb A (1987) Biokinetics of and discrimination between dietary RRR and SRR-alpha tocopherols in the male rat. Lipids 22, 163-172.

Johnson NL, Quinn GE, Abassi S, Geodes I, Bowen FW \& Bhutani V (1995) Severe retinopathy of prematurity in infants with birth weights less than 1250 grams: Incidence and outcome of treatment with pharmacologic serum levels of vitamin E in addition to cryopathy from 1985 to 1991. Journal of Pediatrics 127, 632-639.

Kelly FJ (1993) Free radical disorders of preterm infants. British Medical Bulletin 49, 668-678.

Kelly FJ, Rodgers W, Handel J, Smith S \& Hall MA (1990) Time course of vitamin $\mathrm{E}$ repletion in the premature infant. British Journal of Nutrition 63, 631-638.

Kelly FJ, Safavi M \& Cheeseman KH (1992) Tissue $\alpha$-tocopherol status during late fetal and early neonatal life of the guinea pig. British Journal of Nutrition 67, 457-462.

Leth T \& Sondergaard H (1983) Biological activity of all-racalpha-tocopherol and RRR-alpha tocopherol determined by three different bioassays. International Journal of Vitamin and Nutrition Research 53, 297-311.

Mahan DC, Kim YY \& Stuart RL (2000) Effect of vitamin E sources (RRR- or all-rac-alpha tocopherol acetate) and levels on sow reproductive performance, serum, tissue, and milk alpha tocopherol contents over a five-parity period, and the effects on pregnancy. Journal of Animal Science 78, 110-119.

Mino M \& Nishino H (1973) Fetal and maternal relationship in serum vitamin E level. Journal of Nutrition Science and Vitaminology 19, 475-482.

Njeru CA, McDowell LR, Wilkinson NS, Linda SB \& Williams SN (1994) Pre- and postpartum supplemental DL-alpha tocopheryl acetate effects on placental and mammary vitamin $\mathrm{E}$ transfer in sheep. Journal of Animal Science 72, 1636-1640. 
Ogihara T, Nishida Y, Miki M \& Mino M (1985) Comparative changes in plasma and red blood cell alpha tocopherol after administration of DL-alpha tocopheryl acetate and D-alpha tocopherol (1985). Journal of Nutrition Science and Vitaminology 31, 169-177.

Ostrea EM, Balun JE, Winkler R \& Porter T (1986) Influence of breast-feeding on the restoration of the low serum concentration of vitamin $\mathrm{E}$ and $\beta$-carotene in the newborn infant. American Journal of Obstetrics and Gynecology 154, 1014-1017.

Schlotke B, Busch L \& Koch F (1978) Untersuchungen zum einflub vitamin-E-armer ernahrung bei sauen wahrend der graviditat auf den vitamin-E status de ferkel in der neugeborenenphase (Studies on the effect of vitamin $\mathrm{E}$ deficient diet in sows during pregnancy on the vitamin $\mathrm{E}$ status of newborn piglets). Zentralblatt fur Veterinarmedizin 25, 474-478.

Speer ME, Blifeld C, Rudolph AJ, Chadda P, Holbein B \& Hittner H (1984) Intraventricular hemorrhage and vitamin $E$ in the very low-birth-weight infant: Evidence for efficacy of early intramuscular vitamin E administration. Pediatrics 74, 1107-1112.
Traber MG (1996) Biokinetics of vitamin E. In Handbook of Antioxidants, pp. 43-61 [E Cadenas and L Packer, editors]. New York: Marcel Dekker, Inc.

United States Pharmacopeia (1985) The United States Pharmacopeia, 21st revised ed. Rochville, MD: United States Pharmacopeial Convention.

Weiser H \& Vecchi M (1981) Stereoisomers of alpha-tocopheryl acetate characterization of the samples by physico-chemical methods and determination of biological activities in the rat resorption-gestation test. International Journal of Vitamin and Nutrition Research 51, 100-113.

Weiser H, Riss G \& Kormann AW (1996) Biodiscrimination of the eight alpha tocopherol stereoisomers results in preferential accumulation of the four $2 \mathrm{R}$ forms in tissues and plasma of rats. Journal of Nutrition 125, 2539-2549.

Zhang Z-H, Qi-Huo Z \& Yue H (1987) Maternal-fetal transfer and developmental changes in permeability of blood-brain barrier for vitamin $\mathrm{E}$ in rat. Chinese Medical Journal 100, 731-734. 